Semin Respir Crit Care Med. 2011 February ; 32(1): 10-21. doi:10.1055/s-0031-1272865.

\title{
Lung Cancer in Never Smokers
}

\author{
Ping Yang, M.D., Ph.D. ${ }^{1}$ \\ ${ }^{1}$ Department of Health Sciences Research, College of Medicine, Mayo Clinic, Rochester, \\ Minnesota.
}

\section{Abstract}

Lung cancer in never smokers (LCINS) has lately been recognized as a unique disease based on rapidly gained knowledge from genomic changes to treatment responses. The focus of this article is on current knowledge and challenges with regard to LCINS expanded from recent reviews highlighting five areas: (1) distribution of LCINS by temporal trends, geographic regions, and populations; (2) three well-recognized environmental risk factors; (3) other plausible environmental risk factors; (4) prior chronic lung diseases and infectious diseases as risk factors; and (5) lifestyles as risk or protective factors. This article will also bring attention to recently published literature in two pioneering areas: (1) histological characteristics, clinical features with emerging new effective therapies, and social and psychological stigma; and (2) searching for susceptibility genes using integrated genomic approaches.

\section{Keywords}

Lung cancer; never smokers; environmental risk factors; genetic predisposition; molecular target therapy

\section{OVERVIEW}

Never smokers in the context of lung cancer have been commonly defined as people who have smoked less than 100 cigarettes in their lifetime. ${ }^{1}$ In spite of the public impression that the majority of lung cancer patients are smokers, over one-half of lung cancer cases diagnosed today are never smokers or former smokers, and women are disproportionally affected among never smokers. Physicians and scientists have long recognized that lung cancer in never smokers (LCINS) is a very different disease than lung cancer in smokers. A few comprehensive reviews of the biology, diagnosis, and treatment of LCINS have been recently published ${ }^{1-5}$ and serve as the tangible background of epidemiology and risk factors described here.

\section{DESCRIPTIVE EPIDEMIOLOGY OF LCINS: PAST AND PRESENT}

Long before the advent of cigarette smoking, primary lung cancer was first recognized as a distinct disease in $1761^{6,7}$ and was further described in different aspects 50 years later in $1810 .^{7,8}$ Almost another century later between 1899 and 1911, diagnosing lung cancer in living patients was still rare; even autopsy-identified cases were uncommon (i.e., fewer than 1/1000). ${ }^{9-12}$ During the 20th century, population-based data on lung cancer rates (incidence or mortality) among men in Western countries were dominated by the effects of active

Copyright $(2011$ by Thieme Medical Publishers, Inc.

Address for correspondence and reprint requests: Ping Yang, M.D., Department of Health Sciences Research, College of Medicine, Mayo Clinic, 200 First St. SW, Rochester, MN 55905 (yang.ping@ mayo.edu).. 
cigarette smoking; therefore, by the early 1930s when national mortality statistics were first reported, few data were available for never smokers. Because few women actively smoked during that time, population data on lung cancer in women largely reflected the background rates. ${ }^{13}$ Since the 1930 s in the United States and the world, lung cancer rates exponentially increased (peaked at 100/100,000 for men in the late 1980s and currently a plateau at $55 / 100,000$ for women) as a consequence of pandemic cigarette smoking, but remain relatively stable in never smokers ( 10 to 20/100,000). ${ }^{3,14}$ More recent data between 1992 and 2000 from the European Prospective Investigation into Cancer and Nutrition (EPIC) cohort of 519,978 participants, the age-standardized incidence rates of LCINS (aged 35 to 79 years) were 6.6 and 7.1 per 100,000 person-years for men and women, respectively. ${ }^{15}$ Differences in incidence estimates across studies are more likely due to the variation in the definition of never smokers, specific populations for standardized adjustments, and surrogate measures through mortality data.

As highlighted by Samet et al and Subramanian et al, ${ }^{3,16}$ LCINS increases with age but is similar between men and women. Little evidence supports the suggested trend that lung cancer risk is increasing over time in the general population outside the context of tobacco smoking. Large geographical differences in lung cancer risk in never smokers exist; the reported lowest rates are in Africa and India, whereas the highest rates are in Far East Asian countries. ${ }^{3,16}$ In the United States, among patients with non-small-cell lung cancer (NSCLC) that was diagnosed younger than 40 years of age, there is a greater representation of African Americans, Asians, or Pacific Islanders. ${ }^{3,16}$

\section{CURRENT KNOWLEDGE REGARDING RISK FACTORS}

Radon gas and its progeny were the first identified environmental causes of lung cancer in eastern Europe ${ }^{17}$; the original case report of respiratory malignancy in underground miners was published in $1879 .{ }^{18}$ Numerous subsequent epidemiological studies, ${ }^{19}$ clearly in never smokers, were Navajo uranium miners in the United States; cumulative evidence over the decades points to the relative risk of lung cancer as high as greater than 20 over the general population. ${ }^{20-23}$ Beyond radon and miners, public awareness and scientific investigations of why never smokers in the general population develop lung cancer have been increasing in the past 3 decades.

Secondhand smoking (SHS), residential radon, and indoor air pollution are the top three environmental factors that have been hypothesized, studied, and reported. In the United States, $20 \%$ of LCINS could be contributed to SHS with varied estimated risk ratios (RRs) or odds ratios (ORs) at 1.2 to $2.0^{24,25}$; SHS in childhood (before age 16) significantly increases the risk of squamous-, small- and large-cell carcinomas combined $(\mathrm{OR}=2.1,95 \%$ CI, 1.0 to 4.3$).{ }^{26}$ Up to $12 \%$ of LCINS could be attributed to indoor residential radon residues with varied estimated RRs over 3.0. ${ }^{27,28}$ In Asian countries, indoor air pollution (combustion of coal and biomass, and cooking fumes in the household) is considered the leading risk factor in women. ${ }^{29}$ In Germany, second to cigarette smoking, exposure to indoor radon and its decay products is the leading cause of lung cancer in the general population, with an estimated 8 to $16 \%$ increased risk for every $100 \mathrm{~Bq} / \mathrm{m}^{3} .{ }^{30}$

Other reported and suggested environmental risk factors among never smokers are plausible but with insufficient or inconsistent evidence; these include outdoor air pollution, ionizing radiation from radiation therapy and atomic bomb exposure, and known and suspected occupational agents containing carcinogens. ${ }^{3}$ The available evidence does not allow accurate risk estimation in never smokers only, exemplified by a newly published meta-analysis of painters. ${ }^{31}$ 
Preexisting chronic lung diseases have been studied in association with lung cancer risk, predominantly among smokers and a few separately in never smokers, including asthma, idiopathic interstitial disease, fibrotic disorders, emphysema, and chronic obstructive pulmonary disease (COPD). ${ }^{3,32}$ Chronic bronchitis in never-smoking women in Yunnan, China, where exposure to indoor smoky coal combustion is common, has been associated with increased lung cancer risk. ${ }^{33}$ Patients with COPD, emphysema, idiopathic pulmonary fibrosis, or other fibrotic disorders are at increased risk for lung cancer, ${ }^{34-37}$ but this risk has not been clearly defined in never smokers. ${ }^{38}$

History of infectious diseases, such as tuberculosis (TB), human immunodeficiency virus (HIV), Epstein-Barr virus (EBV), and human papillomavirus (HPV), and infections with Chlamydia pneumoniae, Microsporum canis, and Helicobacter pylori have been suspected to increase risk for lung cancer. Except for tuberculosis, results have not been conclusive with regard to LCINS. ${ }^{29,39-44}$ One study found that, compared to those without TB, female never smokers with TB had approximately an eight-fold increase in lung cancer risk but not in smokers. ${ }^{45}$ Another study reported EBV or HPV being unlikely to be important etiological agents in lung adenocarcinoma, regardless of smoking status. ${ }^{46}$

Regarding reproductive history and hormonal supplements, both endogenous and exogenous, estrogen may be involved in the etiology of lung cancer. ${ }^{47-49}$ Pains or mental tension related to menses and quantity of menstrual flow were reported to be inversely associated with LCINS ${ }^{26}$; hormone replacement therapy may increase LCINS for middleaged women ${ }^{50}$; and oral contraceptives may reduce this risk, but likely with marginal public health benefit. ${ }^{51,52}$

Lifestyle, dietary patterns and supplements, and physical activity have been explored as risk or protective factors for developing LCINS in the past 10 years. An expert panel from the World Cancer Research Fund and the American Institute for Cancer Research concluded that fruits and foods containing carotenoids and isoflavone likely protect against lung cancer. Limited evidence suggests nonstarchy vegetables and selenium to be protective against lung cancer; and inconsistent evidence suggests high-dose retinol supplements, consumption of red meat, processed meats, total fat, and butter to be risk factors of lung cancer. ${ }^{26,53-57}$ Wine drinking at higher frequency than once per month may reduce the risk of adenocarcinoma (OR $=0.46,95 \% \mathrm{CI}, 0.23$ to 0.92$).{ }^{26}$ Increased physical activity has been associated with decreased lung cancer risk, but this is mostly reported in smokers. ${ }^{58-60}$ A recent study has evaluated lung cancer mortality in relation to cardiorespiratory fitness (CRF) in 38,000 men who were 20-84 years of age, without history of cancer, and received a preventive medical examination at Cooper Clinic in Dallas, Texas, between 1974 and 2002. CRF was quantified as maximal treadmill exercise test duration and was grouped for analysis as low, moderate, and high. After adjustment for age, examination year, body mass index, smoking, drinking, physical activity, and family history of cancer, lung cancer risk was significantly lower in moderate or high CRF groups than in the low group, regardless of smoking status but more pronounced in smokers. ${ }^{61}$

\section{Histopathological and Clinical Features: Distinctions from Smokers}

In the search for causes and biological mechanisms of LCINS, understanding the histopathological and clinical features may reveal important clues. A temporal trend has long been observed in the distribution of lung tumor histological type (i.e., shifting from squamous cell carcinoma to adenocarcinoma). ${ }^{62,63}$ This trend has been attributed to the substantial changes in the characteristics of cigarettes and the patterns of deposition and dosages of carcinogens inhaled. ${ }^{64}$ Noted in never smokers, adenocarcinoma has always been the predominant histological type with varied percentage of squamous cell carcinoma by sex and exposure history to secondhand smoke. ${ }^{65-67}$ Changes in subtypes within a histological 
main type (e.g., adenocarcinoma among never smokers) have not been adequately studied. ${ }^{68}$ Because never smokers tend to develop adenocarcinoma, there has been a viewpoint that adenocarcinoma of the lung is weakly or not associated with cigarette smoking. ${ }^{69}$ If this were true, one would expect that lung cancer before the cigarette smoking era would have been primarily adenocarcinoma. However, one of the earliest published documents (1902) that reported histological subtypes of primary lung cancer on 50 consecutive cases reported $32(64 \%)$ being squamous cell carcinoma, two (4\%) adenocarcinoma, and $16(32 \%)$ other lung cancer types. Thus adenocarcinoma might not be the predominant lung cancer type in the absence of tobacco smoke, ${ }^{12}$ implying that beyond the histological type, lung cancer may not be the same disease among never smokers before and during the pandemic era of cigarette smoking.

\section{HETEROGENEOUS NATURE OF ADENOCARCINOMA: REVISITING BRONCHIOLOALVEOLAR CARCINOMA}

Looking into the heterogeneous nature within lung adenocarcinoma, a subtype, namely bronchioloalveolar carcinoma (BAC) is disproportionally more common in never smokers, women, and Asians ${ }^{70,71}$; patients with BAC experience much better prognosis than patients with other subtypes of adenocarcinoma and may require a different management guideline from other NSCLC patients. ${ }^{71,72}$ As shown in a study of 78 pure BAC cases diagnosed and treated at Mayo Clinic between 1997 and 2008, 1-year and 5-year survival rates were 94.8\% and $83.5 \%$, respectively, ${ }^{68}$ supporting that genuine pure BAC may be considered more similar to atypical adenomatous hyperplasia. ${ }^{71}$ To fully distinguish and classify pure BAC remains challenging pathologically but necessary for two major reasons: not to have ambiguity in aggressively treating invasive adenocarcinoma and to avoid overtreating a noninvasive disease.

Equally important, understanding the unique and overlapping biological basis between BAC and adenocarcinoma could provide useful markers in predicting the aggressiveness of BAC tumors and adenocarcinomas with a prominent BAC component. Promising markers began to emerge 2 decades ago, including DNA methylation of the glutathione S-transferase P1 gene (GSTP1), cyclin-dependent kinase inhibitor 2A [p16(INK4a)], Ras association domain family member 1 (RASSF1A), and Cadherin 13, H-cadherin (heart) gene (CDH13) ${ }^{73,74}$; mutation of epidermal growth factor receptor (EGFR), p53, and K-ras ${ }^{75-82}$; loss of heterozygosity (LOH) on chromosome 3p, 5q, 9p, and 17p $\mathrm{p}^{78,79,83}$; and patterns of global tumor gene expression profiling 84 (all of which had relatively small sample sizes) were lacking smoking-specific information or showed inconsistent findings. A recent review ${ }^{85}$ captured significant genotype-phenotype correlations between EGFR mutations and the presence of a BAC component, a micropapillary pattern, and the hobnail cell type; patients with these pathological features might benefit from therapy with EGFR tyrosine kinase inhibitors (EGFR-TKI). To conclude, more comprehensive and systematic research is required at multiple genomic levels to achieve the goal of differentiating tumor nature in accordance with pathological and clinical features of LCINS.

\section{THERAPEUTIC MOLECULAR TARGETS: PATIENTS' SPECIFIC TREATMENT OPTIONS}

Besides etiology and tumor histology, clinically significant differences between never smokers and smokers have been consistently recognized in terms of prognosis and response to therapy, ${ }^{86-88}$ with a few exceptions. ${ }^{89}$ Although they usually present at an advanced stage with nonspecific symptoms, never smokers have a better natural history and prognosis with therapy than smokers if their tumors contain EGFR mutation (L858R) and they undertook EGFR-TKI treatment, ${ }^{1,90-92}$ particularly among female patients with adenocarcinoma. ${ }^{93}$ In 
addition to tumor specimens, the EGFR mutations in the serum and the pleural effusion from advanced NSCLC patients can be detected and clinically useful. ${ }^{94}$ Erlotinib, an EGFR-TKI drug, is a standard of treatment for metastatic NSCLC after failure of first-line therapy. Grade 2 to 3 skin toxicity is a sentinel response indicative for significantly prolonged progression-free survival (PFS) and overall survival (OS). ${ }^{95}$ Gefitinib, a small molecule that prevents adenosine triphosphate (ATP) binding in the tyrosine kinase domain of the EGFR, has been demonstrated to be superior to carboplatin/ paclitaxel in a phase III clinical trial (the IRESSA Pan-Asia Study) as first-line treatment for pulmonary adenocarcinoma among never smokers or former light smokers in East Asia. ${ }^{96}$ Gefitinib is anticipated to be used in pretreated and selected chemotherapy-naive patients with advanced NSCLC and with the presence of an EGFR mutation. ${ }^{97}$

\section{Deeper and Broader Command in EGFR-TKI-Based Therapy: Responses, Resistance, Toxicities, and Remedies}

The other side of the successful story of EGFR-TKI-based therapy is that the majority (over $80 \%$ ) of unselected NSCLC patients do not respond, and patients who responded initially invariably relapse later with resistant disease. Therefore, EGFR-specific TKI drugs, as single agents, will unlikely make a high impact on curing lung cancer. ${ }^{98}$ Acquired resistance is defined as systemic progression of disease ${ }^{99}$ during continuous treatment with gefitinib or erlotinib within the last 30 days, and no intervening systemic therapy. ${ }^{100}$ Three challenges to overcome resistance to this group of promising drugs are how to timely and effectively (1) predict true responses, (2) prevent acquired resistance from occurring, and (3) defy resistance. The optimal alternative therapeutic approach after a failed one remains to be defined.

Various predictive markers have been reported beyond the primary mutation, including secondary mutations of EGFR (T790M, S768I, and V769L), cMET (mesenchymal-epithelial transition factor) amplification, EGFR gene copy numbers and status of ligands, and changes in other HER (herceptin) family genes or molecules downstream to EGFR including K-ras or AKT (protein Kinase $\beta$-alpha). ${ }^{101-105}$ Other mechanistic markers include epithelial to mesenchymal transition, ${ }^{106}$ and higher expression levels of E-cadherin. ${ }^{107,108}$ To utilize these molecular markers in predicting responses, resensitizing and enhancing EGFR-TKI treatment outcomes are under rapid development.

Imaging approaches may offer early identification of tumor response in EGFR-dependent NSCLC. One has been reported, namely $3^{\prime}$-Deoxy- $3^{\prime}$-[(18)F]-fluoro-L-thymidine ([(18)F]FLT) [(18)F]FLT positron emission tomography (PET) imaging has been presented as one appropriate method. ${ }^{109}$

Acquired EGFR-TKI resistance should be managed assertively and properly. Options currently in practice include using erlotinib as salvage treatment after failure to gefitinib, ${ }^{110,111}$ taxane-based regimens, ${ }^{112}$ and single-agent pemetrexed. ${ }^{113}$ Promising alternatives have been actively investigated and include MET small molecule inhibitor, SU11274, which targets EGFR-T790M mutation ${ }^{114}$ (an irreversible EGFR TKI BIBW-2992) and the EGFR-specific antibody cetuximab. ${ }^{115}$ Other alternatives include receptor tyrosine kinase pathways, such as insulingrowth factor 1 receptor (IGF-1R) and fibroblast growth factor receptors (FGFRs) (with high degree of homology with vascular endothelial growth factor receptors [VEGFRs] and platelet-derived growth factor receptors [PDGFRs]). ${ }^{98}$ Finally, hsp90 inhibitors (e.g., 17-allylamino-17-demethoxygeldanamycin or 17-AAG) have been demonstrated to be effective to treatment de novo and acquired resistance to EGFR TKIs. ${ }^{116}$ 
Although systemic chemotherapy is usually avoided during whole-brain radiation therapy (WBRT) to minimize or avoid toxicities, concurrent administration of erlotinib or gefitinib has been practiced. Gefitinib treatment for never smokers with adenocarcinoma and asymptomatic synchronous brain metastasis showed promising antitumor activity against both intracranial and extracranial tumors. ${ }^{117}$ However, serious toxicity related to erlotinib was reported in a retrospective evaluation of seven cases; three patients responded, yet three deaths occurred without clear signs of disease progression. Unanticipated severe toxicities include grade 3 hepatotoxicity, hyponatremia, mental status changes, grade 3 to 4 thrombocytopenia, and grade 4 neutropenia with sepsis. ${ }^{118}$ The benefits and toxicities of erlotinib during WBRT need to be thoroughly assessed with prospective trials.

In contrast to most aspects of lung cancer where most of what is known is among smokers, the mutation status and clinical relevance of EGFR in smokers and male patients are much less clear. Smokers do carry EGFR mutations, and a decreased EGFR mutation rate with increased smoking dose was observed in a Korean study: $48.0 \%$ in never smokers, $23.1 \%$ in former smokers, and $11.4 \%$ in current smokers. ${ }^{119}$ Mutations in exon 19 or 21 were associated with females $(p<0.0001)$, never smokers $(p<0.0001)$, and adenocarcinoma ( $p<$ $0.0001)$; whereas, mutations in exon 20 were more common in smokers. In virtually all clinical trials published to date, randomization in design and analysis of outcome by smoking status have not been reported.

\section{Tale of Anaplastic Lymphoma Kinase}

The fusion between echinoderm microtubule-associated protein-like 4 (EML4) and anaplastic lymphoma kinase (ALK), through a small inversion within chromosome 2 p, has recently been identified in a subset of lymphoma and NSCLC patients. ${ }^{120,121}$ Other fusion partners of ALK include nucleophosmin (NPM), tropomyosin 3 (TPM3), 5aminoimidazole-4-carboxamide ribonucleotide formyltransferase/IMP cyclohydrolase (ATIC), TRK-fused gene (TFG), cysteinyl-tRNA synthetase (CARS), and clathrin, heavy chain (Hc) (CLTC). ${ }^{122}$ The EML4-ALK fusions are mutually exclusive with mutations in the EGFR, KRAS, and v-erb-b2 erythroblastic leukemia viral oncogene homolog 2 (ERBB2) genes, ${ }^{123}$ except one case was reported to have concurrent deletion in EGFR exon 19 and fusion of EML4-ALK in a Chinese woman with an adenocarcinoma. ${ }^{122}$ The EML4ALK fusion appears to be tightly associated with a higher level of ALK mRNA expression but not EML4 expression. ${ }^{122}$ EML4-ALK is oncogenic both in vitro and in vivo, and ALK kinase inhibitors are quite effective in preclinical model systems and have entered clinical development. Remarkably, clinical efficacy has been observed in NSCLC patients harboring EML4-ALK translocations ${ }^{121}$; these patients are more likely to be younger men who were never or light smokers with lung adenocarcinoma. ${ }^{124}$ There is a trend toward improved survival for patients with the EML4-ALK fusion; but an opposite trend is found in another study focusing on never smokers. ${ }^{122,125}$ However, these patients do not benefit from EGFR TKIs and may benefit from ALK-targeted agents. ${ }^{24,126}$

\section{SOCIAL AND PSYCHOLOGICAL STIGMA: SIMILARITIES TO SMOKERS}

The well-recognized stigma of lung cancer is directly related to cigarette smoking. That is, the unfavorable public sentiment toward the medical cost burden and lost productive lives due to smoking has led to the common perception that lung cancer is self-inflicted, and affected patients are blamed. A group of researchers examined the effects of an individual's smoking status on social and psychological aspects of lung cancer, as summarized by Raleigh. ${ }^{127}$ Interestingly, never smokers with lung cancer did not differ from smokers with the disease in major social and psychological stigma. The social stigma that lung cancer is a preventable disease affects never smokers, who felt unjustly blamed for their illness and 
were assumed to be smokers. The psychological impact of having lung cancer included feelings of guilt and depression, the same for both smokers and never smokers. ${ }^{127}$

\section{Lung Cancer Susceptibility Genes Found through Integrated Genomic Research}

In spite of the exceptionally high contributable risk of tobacco smoke, genetic susceptibility to lung cancer development has been recognized for more than 50 years. Two important pieces of evidence suggesting an inherited predisposition are (1) lung cancer only develops in a minority of heavy and long-term smokers, and (2) it aggregates in families independent of smoking. ${ }^{128}$ However, identifying and characterizing lung cancer-causing genes have been hindered by difficulty in assembling enough informative pedigrees (for genetic linkage studies of rare and high-penetrance genes) or recruiting sufficient biological samples from never smokers (for case-control studies of common and low-penetrance genes). Even in the genomic era with effective high throughput technology and feasible genomewide association strategies, fewer than 10 studies have been reported to specifically identify lung cancer susceptibility genes. ${ }^{129}$ Most of these studies were in primarily smokers; nonetheless, candidate genes identified from these studies are important in understanding inherited predisposition to developing lung cancer and in elucidating mechanistic interactions and causal roles between genetic background and environmental exposures.

\section{RARE AND HIGH-PENETRANCE GENES}

In 2004, the first major susceptibility locus influencing lung cancer risk was localized to chromosome 6q23-25 using a genomewide linkage analysis of 52 extended pedigrees ${ }^{130}$ and was refined to confer particularly higher risks to never and light smokers. ${ }^{131}$ In this chromosome region, $R G S 17$ was identified as the novel candidate gene in familial lung cancer, ${ }^{132}$ and $p 34$ was a novel tumor suppressor gene in sporadic lung cancer ${ }^{133}$; roles of these two genes in never smokers need to be defined.

\section{COMMON AND LOW-PENETRANCE GENES}

Between 2007 and 2009, eight genomewide association (GWA) single-nucleotide polymorphisms (SNP) studies have reported association between chromosome loci and lung cancer susceptibility in samples of primarily smokers. ${ }^{134-141}$ Of the five top candidate SNPs, two (rs402710 and rs2736100) are located in chromosome 5p15.33, containing the human telomerase reverse transcriptase (TERT) gene and the cleft lip and palate transmembrane 1 like (CLPTM1L, alias CRR9) gene; the overall estimated allelic ORs are under 1.2. ${ }^{137}$ Two of the remaining three SNPs (rs8034191 and rs16969968) are located in chromosome 15q25 containing six known genes [allelic ORs between 1.21 and 1.45] ${ }^{135}$; three of the six genes encode nicotinic acetylcholine receptor subunits (CHRNA5-cholinergic receptor nicotinic a 5, CHRNA3 - cholinergic receptor nicotinic a 3, and CHRNB4-cholinergic receptor nicotinic $\beta 4$ ); the other three genes are IREB2 (iron-responsive element-binding protein 2), PSMA4 (implicated in DNA repair), and aminoglycoside phosphotransferase domaincontaining protein 1(LOC123688, unknown function). The fifth top SNP (rs4324798) is located in chromosome 6p21.33 within an extended region near the major histocompatibility complex containing more than 20 genes, and five validation studies provided evidence of association with lung cancer risk, at an OR of 1.28 (1.16 to 1.40). ${ }^{135}$ However, two small subsets of never smokers did not support the observed SNP associations in smokers, ${ }^{139,142}$ and additional validation studies are required to elucidate whether nicotine dependence genes are in the causal pathway to lung cancer in never smokers.

In 2010, the first GWA study reported genetic variants at chromosome 13q31.3 being associated with susceptibility to LCINS through regulating GPC5 expression. ${ }^{143-145}$ Glypican 5 (GPC5) is a member of the glypican gene family and has eight exons encoding 
572 amino acids ${ }^{146}$; glypicans are a family of heparan sulfate proteoglycans (HSPGs) that are widely distributed in mammalian tissues and interact with many proteins, including growth factors, chemokines, and structural proteins of the extracellular matrix to influence cell growth, differentiation, and the cellular response to the environment. ${ }^{147}$ Landi et al performed a meta-analysis, combining previously published data from GWA studies, supporting the association between a SNP rs2352028 (representing the GPC5 gene) and lung adenocarcinoma risk ${ }^{143-145}$; however, this meta-analysis included very heterogeneous studies: one had smokers in the control group, two had different definitions of "never smokers," two had fewer than 40 cases and one had a case-control ratio over 1:170, and three had no or minimal data on potential confounders. To validate (or refute) a candidate SNP that has gone through discovery and replication in four independent studies requires an adequately powered study using more refined cases and controls, with complete epidemiological data (e.g., passive smoking, prior COPD diagnosis, and family history of lung cancer) to control for potential biases in the initial results. ${ }^{143-145}$

\section{INTERACTIONS BETWEEN ENVIRONMENTAL AND GENETIC FACTORS}

Molecular epidemiology has been thriving in cancer etiologic research, particularly in dissecting how genetic factors modify host responses to environmental insults. A relatively common genotype, as normal variants or polymorphisms, can change the physiological response to carcinogens and can modify meaningfully the cancer burden in populations, even at a low level of exposure to an environmental risk factor. The classic showcase of gene-environmental interaction is the xenobiotransformation system (activating and detoxifying metabolic pathways) genetic polymorphisms and exogenous carcinogen exposure in the causes of LCINS, ${ }^{148}$ for example, the germline variants in genes whose products activate [cytochrome P450 1A1 (CYP1A1)] and detoxify [glutathione Stransferases M1 (GSTM1) and T1 (GSTT1)] chemical carcinogens. For carcinogen activating enzymes, there is no increase in risk of LCINS for CYP1A1 Msp I genotypes, with or without SHS exposure history. ${ }^{149}$ Among genetic polymorphisms of the detoxifying enzymes, two studies found that cases with SHS exposure history were more than twice as likely to be deficient in GSTM1 activity, reaching an over sixfold excess risk in those exposed to 55 pack-years of SHS (produced by an active smoker, within a confined space such as home or office). ${ }^{150,151}$ Because 30 to $50 \%$ of the population carries the deficient or null GSTM1 genotype, such an effect modifier could be an important contributor to LCINS. ${ }^{149-151}$ For another detoxifying enzyme N-acetyl transferase 2 (NAT2), a typical gene-environmental interaction with opposite directions between two genotypes has been reported: the slow acetylator genotype may confer an increased risk of LCINS; whereas, the rapid acetylator genotype may produce a steeper risk gradient among smokers with increasing pack-year doses. ${ }^{151}$

DNA repair genes encoding $\mathrm{x}$-ray cross-complementing group 1 (XRCC1) and xeroderma pigmentosum group D (XPD) are two major DNA repair proteins. Polymorphisms of these two genes have been associated with altered DNA repair capacity and lung cancer risk. The adjusted ORs of XRCC1 Arg399Gln polymorphism (Gln/Gln vs Arg/Arg) was 1.3, but for never smokers, the adjusted OR was 2.4. ${ }^{152,153}$ XPD Arg156Arg polymorphism was associated with increased risk for lung cancer $(\mathrm{OR}=2.5 ; p 0.03)$ adenocarcinoma of the lung $(\mathrm{OR}=$ and $=5.6 ; p 0.005)$ never smokers only. ${ }^{154}$ The association= among of exon 5 polymorphisms in the $A G T(\mathrm{O}(6)$-alkylguanine DNA alkyltransferase) gene and lung cancer risk was assessed in never smokers exposed to SHS by determining the frequencies of the Gly(160)Arg, Ile(143)Val, and Lys(178)Arg variant alleles. Never smoking individuals with the codon (143) Val and (178)Arg variant alleles were at 2.7-fold increased risk of developing lung adenocarcinoma. ${ }^{155}$ 
Polymorphisms in genes involved in the inflammatory response and interaction with nonsteroidal antiinflammatory drug (NSAID) use in relation to lung cancer risk have also been reported. The functional SNPs in interleukin (IL)-1B T-31C, IL6 G-174C, IL8 T-251A, IL10 C-592T, cytochrome C oxidase subunit II (COX2) C8473T, COX2 A-1195G, and peroxisome proliferator-activated receptor gamma (PPARG2) Pro(12)Ala were studied. Never smokers carrying the variant allele were at a five-fold higher lung cancer risk than those carrying the homozygous wild-type allele. ${ }^{156}$ Olivo-Marston et al have hypothesized a positive association between childhood SHS exposure and lung cancer risk that would be modified by genetic polymorphisms in the mannose-binding lectin-2 (MBL2) gene resulting in well-known functional changes in innate immunity. ${ }^{157} \mathrm{~A}$ functional MBL2 haplotype was found to be associated with high circulating levels of MBL, and increased MBL2 activity was associated with doubled lung cancer risk among individuals exposed to childhood SHS. The indicated high-risk haplotype corresponds to a known overactive complement pathway of the innate immune system. ${ }^{157}$ Genetic polymorphisms in innate immunity genes may also hold a role in the genesis of lung cancer caused by polycyclic aromatic hydrocarbons (PAH) -containing coal smoke. ${ }^{158}$ The inflammatory response induced by coal smoke components may promote lung tumor development. The gene regions arachidonate 12lipoxygenase (ALOX) 12B/ALOX15B and kallikrein-related peptidase (KLK)2 were associated with increased lung cancer risk globally. In addition, there were positive interactions between KLK15 rs3745523 and smoky coal use and between Fc fragment of IgE, low affinity II (FCER2) rs7249320, and KLK2 rs2739476 (OR: 10.8; $p=0.003$ ). ${ }^{159}$

Asbestos exposure, manganese superoxide dismutase (MnSOD) genotype, and lung cancer risk has been investigated, with no conclusive evidence for never smokers. ${ }^{160,161}$ There has not been a study reporting genetic modifying effects on exposures to residential radon and indoor air pollutions.

In summary, research on LCINS may contribute to understanding lung cancer in general. Specifically, biological determinants and mechanisms of genetic predisposition to lung cancer may be more evident in never smokers exposed to SHS, radon, or other agents, similar to the individual susceptibility in smokers.

\section{Acknowledgments}

This work was funded in part by National Institutes of Health grants: R01 CA 80127, R01 CA 84354, and R01 CA 115857. The author thanks Susan Ernst, MA, for her technical assistance with the manuscript.

\section{REFERENCES}

1. Subramanian J, Govindan R. Lung cancer in 'never-smokers': a unique entity. Oncology (Williston Park). 2010; 24(1):29-35. [PubMed: 20187318]

2. Rudin CM, Avila-Tang E, Samet JM. Lung cancer in never smokers: a call to action. Clin Cancer Res. 2009; 15(18):5622-5625. [PubMed: 19755390]

3. Samet JM, Avila-Tang E, Boffetta P, et al. Lung cancer in never smokers: clinical epidemiology and environmental risk factors. Clin Cancer Res. 2009; 15(18):5626-5645. [PubMed: 19755391]

4. Sun S, Schiller JH, Gazdar AF. Lung cancer in never smokers-a different disease. Nat Rev Cancer. 2007; 7(10):778-790. [PubMed: 17882278]

5. Scagliotti GV, Longo M, Novello S. Nonsmall cell lung cancer in never smokers. Curr Opin Oncol. 2009; 21(2):99-104. [PubMed: 19532009]

6. Lung cancer. http://en.wikipedia.org/wiki/Lung_cancer\# cite_note-AUTOREF27-140

7. Morgagni, GB. De sedibus et causis morborum per anatomen indagatis. 1761. http://en.wikipedia.org/wiki/Lung_- cancer\#cite_note-AUTOREF27-140

8. Bayle, GL. Recherches sur la phtisie pulmonaire. Paris, France: 1810. http://en.wikipedia.org/wiki/Lung_cancer\#cite_ref-AUTOREF28_141-0 
9. Fried BM. Primary carcinoma of the lung. Bronchiogenic cancer: a clinical and pathological study. Medicine. 1931; 10:373-508.

10. Karsner HT, Saphir O. Small cell carcinomas of the lung. Am J Pathol. 1930; 6(5):553-562. 3. [PubMed: 19969929]

11. Weller CV. The pathology of primary carcinoma of the lung. Archives of Pathology. 1929; 7:478519.

12. Rosenblatt, MB.; Lisa, JR. Bronchial adenoma. In: Cancer of the Lung: Pathology, Diagnosis, and Treatment. Oxford University Press; New York: 1956. p. 259-312.

13. United States Surgeon General's Advisory Committee on Smoking and Health. Smoking and Health: Report of the Advisory Committee to the Surgeon General of the Public Health Service. U.S. Department of Health, Education and Welfare, Public Health Service, Government Printing Office; Washington, DC: 1964. p. 19-21.

14. Wakelee HA, Chang ET, Gomez SL, et al. Lung cancer incidence in never smokers. J Clin Oncol. 2007; 25(5):472-478. [PubMed: 17290054]

15. Johansson M, Relton C, Ueland PM, et al. Serum B vitamin levels and risk of lung cancer. JAMA. 2010; 303(23):2377-2385. [PubMed: 20551408]

16. Subramanian J, Morgensztern D, Goodgame B, et al. Distinctive characteristics of non-small cell lung cancer (NSCLC) in the young: a surveillance, epidemiology, and end results (SEER) analysis. J Thorac Oncol. 2010; 5(1):23-28. [PubMed: 19934774]

17. National Research Council (NRC) Committee on the Biological Effects of Ionizing Radiations, Board on Radiation Effects Research, Commission on Life Sciences. , editor. Health Risks of Radon and Other Internally Deposited Alpha-Emitters: BEIR. National Academy Press; Washington: 1988.

18. Harting F, Hesse W. Der Lungenkrebs, die Bergkrankheit in den schneeberger Gruben. Viertel Gerichtl Med Oeff Sanitaetswes. 1879; 31(102-132):313-337.

19. Samet JM. Indoor radon levels may be higher than in uranium mines. Radon and lung cancer: how great is the risk? J Respir Dis. 1989; 10:73-83.

20. Archer VE, Wagoner JK, Lundin FE. Lung cancer among uranium miners in the United States. Health Phys. 1973; 25(4):351-371. [PubMed: 4361970]

21. Samet JM, Kutvirt DM, Waxweiler RJ, Key CR. Uranium mining and lung cancer in Navajo men. N Engl J Med. 1984; 310(23):1481-1484. [PubMed: 6717538]

22. Gilliland FD, Hunt WC, Archer VE, Saccomanno G. Radon progeny exposure and lung cancer risk among non-smoking uranium miners. Health Phys. 2000; 79(4):365-372. [PubMed: 11007458]

23. Al-Zoughool M, Krewski D. Health effects of radon: a review of the literature. Int J Radiat Biol. 2009; 85(1):57-69. [PubMed: 19205985]

24. United States Environmental Protection Agency. Respiratory Health Effects of Passive Smoking: Lung Cancer and Other Disorders. U.S. Environmental Protection Agency, Office of Research and Development; Washington, DC: 1992. EPA/600/606-690/006F

25. Yang P, Sun Z, Krowka MJ, et al. Alpha1-antitrypsin deficiency carriers, tobacco smoke, chronic obstructive pulmonary disease, and lung cancer risk. Arch Intern Med. 2008; 168(10):1097-1103. [PubMed: 18504338]

26. Zatloukal P, Kubík A, Pauk N, Tomásek L, Petruzelka L. Adenocarcinoma of the lung among women: risk associated with smoking, prior lung disease, diet and menstrual and pregnancy history. Lung Cancer. 2003; 41(3):283-293. [PubMed: 12928119]

27. Thun MJ, Henley SJ, Burns D, Jemal A, Shanks TG, Calle EE. Lung cancer death rates in lifelong nonsmokers. J Natl Cancer Inst. 2006; 98(10):691-699. [PubMed: 16705123]

28. National Research Council (NRC). Committee on Health Risks of Exposure to Radon, Board on Radiation Effects Research, Commission on Life Sciences, ed. Health Effects of Exposure to Radon. (BEIR IV.). National Academy Press; Washington: 1999.

29. Lam WK. Lung cancer in Asian women: the environment and genes. Respirology. 2005; 10(4): 408-417. [PubMed: 16135162]

30. Schmid K, Kuwert T, Drexler H. Radon in indoor spaces: an underestimated risk factor for lung cancer in environmental medicine. Dtsch Arztebl Int. 2010; 107(11):181-186. [PubMed: 20386676] 
31. Guha N, Merletti F, Steenland NK, Altieri A, Cogliano V, Straif K. Lung cancer risk in painters: a meta-analysis. Environ Health Perspect. 2010; 118(3):303-312. [PubMed: 20064777]

32. Harris JM, Johnston ID, Rudd R, Taylor AJ, Cullinan P. Cryptogenic fibrosing alveolitis and lung cancer: the BTS study. Thorax. 2010; 65(1):70-76. [PubMed: 19996344]

33. Liu ZY, He XZ, Chapman RS. Smoking and other risk factors for lung cancer in Xuanwei, China. Int J Epidemiol. 1991; 20(1):26-31. [PubMed: 2066232]

34. Daniels CE, Jett JR. Does interstitial lung disease predispose to lung cancer? Curr Opin Pulm Med. 2005; 11(5):431-437. [PubMed: 16093818]

35. Le Jeune I, Gribbin J, West J, Smith C, Cullinan P, Hubbard R. The incidence of cancer in patients with idiopathic pulmonary fibrosis and sarcoidosis in the UK. Respir Med. 2007; 101(12):25342540. [PubMed: 17870458]

36. Mizushima Y, Kobayashi M. Clinical characteristics of synchronous multiple lung cancer associated with idiopathic pulmonary fibrosis. A review of Japanese cases. Chest. 1995; 108(5): 1272-1277. [PubMed: 7587428]

37. Yousem SA. The pulmonary pathologic manifestations of the CREST syndrome. Hum Pathol. 1990; 21(5):467-474. [PubMed: 2186993]

38. Brenner DR, Hung RJ, Tsao MS, et al. Lung cancer risk in never-smokers: a population-based case-control study of epidemiologic risk factors. BMC Cancer. 2010; 10:285. [PubMed: 20546590]

39. Cheng YW, Chiou HL, Chen JT, et al. Gender difference in human papillomarvirus infection for non-small cell lung cancer in Taiwan. Lung Cancer. 2004; 46(2):165-170. [PubMed: 15474664]

40. Engels EA, Brock MV, Chen J, Hooker CM, Gillison M, Moore RD. Elevated incidence of lung cancer among HIV-infected individuals. J Clin Oncol. 2006; 24(9):1383-1388. [PubMed: 16549832]

41. Kirk GD, Merlo C, O' Driscoll P, et al. HIV infection is associated with an increased risk for lung cancer, independent of smoking. Clin Infect Dis. 2007; 45(1):103-110. [PubMed: 17554710]

42. Laurila AL, Anttila T, Läärä E, et al. Serological evidence of an association between Chlamydia pneumoniae infection and lung cancer. Int J Cancer. 1997; 74(1):31-34. [PubMed: 9036866]

43. Littman AJ, White E, Jackson LA, et al. Chlamydia pneumoniae infection and risk of lung cancer. Cancer Epidemiol Biomarkers Prev. 2004; 13(10):1624-1630. [PubMed: 15466979]

44. Smith JS, Kumlin U, Nyberg F, et al. Lack of association between serum antibodies of Chlamydia pneumoniae infection and the risk of lung cancer. Int J Cancer. 2008; 123(10):2469-2471. [PubMed: 18720403]

45. Hinds MW, Cohen HI, Kolonel LN. Tuberculosis and lung cancer risk in nonsmoking women. Am Rev Respir Dis. 1982; 125(6):776-778. [PubMed: 7091889]

46. Lim WT, Chuah KL, Leong SS, Tan EH, Toh CK. Assessment of human papillomavirus and Epstein-Barr virus in lung adenocarcinoma. Oncol Rep. 2009; 21(4):971-975. [PubMed: 19287995]

47. Paulus JK, Asomaning K, Kraft P, Johnson BE, Lin X, Christiani DC. Parity and risk of lung cancer in women. Am J Epidemiol. 2010; 171(5):557-563. [PubMed: 20123687]

48. Kabat GC, Miller AB, Rohan TE. Reproductive and hormonal factors and risk of lung cancer in women: a prospective cohort study. Int J Cancer. 2007; 120(10):2214-2220. [PubMed: 17278095]

49. Liu Y, Inoue M, Sobue T, Tsugane S. Reproductive factors, hormone use and the risk of lung cancer among middle-aged never-smoking Japanese women: a large-scale population-based cohort study. Int J Cancer. 2005; 117(4):662-666. [PubMed: 15929081]

50. Hampton T. Lung cancer mortality higher in women who used combination hormone therapy. JAMA. 2009; 302(6):615-616. [PubMed: 19671896]

51. Elliott AM, Hannaford PC. Use of exogenous hormones by women and lung cancer: evidence from the Royal College of General Practitioners' Oral Contraception Study. Contraception. 2006; 73(4): 331-335. [PubMed: 16531161]

52. Benowitz NL, Lessov-Schlaggar CN, Swan GE, Jacob PIII. Female sex and oral contraceptive use accelerate nicotine metabolism. Clin Pharmacol Ther. 2006; 79(5):480-488. [PubMed: 16678549] 
53. Key TJ, Allen NE, Spencer EA, Travis RC. The effect of diet on risk of cancer. Lancet. 2002; 360(9336):861-868. [PubMed: 12243933]

54. World Cancer Research Fund International. Food, Nutrition, Physical Activity, and the Prevention of Cancer: A Global Perspective. American Institute for Cancer Research; Washington, DC: 2007.

55. Mulder I, Jansen MC, Smit HA, et al. Seven Countries Study Research Group. Role of smoking and diet in the cross-cultural variation in lung-cancer mortality: the Seven Countries Study. Int J Cancer. 2000; 88(4):665-671. [PubMed: 11058887]

56. Liu Y, Sobue T, Otani T, Tsugane S. Vegetables, fruit consumption and risk of lung cancer among middle-aged Japanese men and women: JPHC study. Cancer Causes Control. 2004; 15(4):349357. [PubMed: 15141136]

57. Shimazu T, Inoue M, Sasazuki S, et al. Japan Public Health Center-based Prospective Study Group. Isoflavone intake and risk of lung cancer: a prospective cohort study in Japan. Am J Clin Nutr. 2010; 91(3):722-728. [PubMed: 20071645]

58. Leitzmann MF, Koebnick C, Abnet CC, et al. Prospective study of physical activity and lung cancer by histologic type in current, former, and never smokers. Am J Epidemiol. 2009; 169(5): 542-553. [PubMed: 19126591]

59. Yun YH, Lim MK, Won YJ, et al. Dietary preference, physical activity, and cancer risk in men: national health insurance corporation study. BMC Cancer. 2008; 8:366. [PubMed: 19077256]

60. Sinner P, Folsom AR, Harnack L, Eberly LE, Schmitz KH. The association of physical activity with lung cancer incidence in a cohort of older women: the Iowa Women's Health Study. Cancer Epidemiol Biomarkers Prev. 2006; 15(12):2359-2363. [PubMed: 17164357]

61. Sui X, Lee DC, Matthews CE, et al. Influence of cardiorespiratory fitness on lung cancer mortality. Med Sci Sports Exerc. 2010; 42(5):872-878. [PubMed: 19996990]

62. Alberg AJ, Ford JG, Samet JM, American College of Chest Physicians. Epidemiology of lung cancer: ACCP evidence-based clinical practice guidelines (2nd edition). Chest. 2007; 132(3, suppl):29S-55S. [PubMed: 17873159]

63. Devesa SS, Bray F, Vizcaino AP, Parkin DM. International lung cancer trends by histologic type: male:female differences diminishing and adenocarcinoma rates rising. Int J Cancer. 2005; 117(2): 294-299. [PubMed: 15900604]

64. Hoffmann D, Hoffmann I. The changing cigarette, 1950-1995. J Toxicol Environ Health. 1997; 50(4):307-364. [PubMed: 9120872]

65. Schneiderman MA, Davis DL, Wagener DK. Lung cancer that is not attributable to smoking. JAMA. 1989; 261(18):2635-2636. [PubMed: 2775347]

66. Liam CK, Pang YK, Leow CH, Poosparajah S, Menon A. Changes in the distribution of lung cancer cell types and patient demography in a developing multiracial Asian country: experience of a university teaching hospital. Lung Cancer. 2006; 53(1):23-30. [PubMed: 16690159]

67. de Andrade M, Ebbert JO, Wampfler JA, et al. Environmental tobacco smoke exposure in women with lung cancer. Lung Cancer. 2004; 43(2):127-134. [PubMed: 14739032]

68. Ebbert JO, Chhatwani L, Aubry MC, et al. Clinical features of bronchioloalveolar carcinoma with new histologic and staging definitions. J Thorac Oncol. 2010; 5(8):1213-1220. [PubMed: 20592627]

69. Yang P, Cerhan JR, Vierkant RA, et al. Adenocarcinoma of the lung is strongly associated with cigarette smoking: further evidence from a prospective study of women. Am J Epidemiol. 2002; 156(12):1114-1122. [PubMed: 12480656]

70. Raz DJ, He B, Rosell R, Jablons DM. Bronchioloalveolar carcinoma: a review. Clin Lung Cancer. 2006; 7(5):313-322. [PubMed: 16640802]

71. Laskin JJ, Sandler AB, Johnson DH. Redefining bronchio-loalveolar carcinoma. Semin Oncol. 2005; 32(3):329-335. [PubMed: 15988687]

72. Travis, WD.; Colby, TV.; Shimosato, Y., et al. Histological Typing of Lung and Pleural Tumours. 3rd ed. Springer-Verlag; New York: 1999. p. 21-47.

73. Gao P, Yang X, Xue YW, et al. Promoter methylation of glutathione S-transferase pi1 and multidrug resistance gene 1 in bronchioloalveolar carcinoma and its correlation with DNA methyltransferase 1 expression. Cancer. 2009; 115(14):3222-3232. [PubMed: 19484794] 
74. Kubo T, Yamamoto H, Ichimura K, et al. DNA methylation in small lung adenocarcinoma with bronchioloalveolar carcinoma components. Lung Cancer. 2009; 65(3):328-332. [PubMed: 19144441]

75. Rusch VW, Reuter VE, Kris MG, et al. Ras oncogene point mutation: an infrequent event in bronchioloalveolar cancer. J Thorac Cardiovasc Surg. 1992; 104(5):1465-1469. [PubMed: 1331621]

76. Marchetti A, Buttitta F, Pellegrini S, et al. Bronchioloalveolar lung carcinomas: K-ras mutations are constant events in the mucinous subtype. J Pathol. 1996; 179(3):254-259. [PubMed: 8774479]

77. Holst VA, Finkelstein S, Yousem SA. Bronchioloalveolar adenocarcinoma of lung: monoclonal origin for multifocal disease. Am J Surg Pathol. 1998; 22(11):1343-1350. [PubMed: 9808126]

78. Yamasaki M, Takeshima Y, Fujii S, Matsuura M, Tagawa K, Inai K. Correlation between morphological heterogeneity and genetic alteration within one tumor in adenocarcinomas of the lung. Pathol Int. 2000; 50(11):891-896. [PubMed: 11107065]

79. Yamasaki M, Takeshima Y, Fujii S, et al. Correlation between genetic alterations and histopathological subtypes in bronchiolo-alveolar carcinoma and atypical adenomatous hyperplasia of the lung. Pathol Int. 2000; 50(10):778-785. [PubMed: 11107049]

80. Gandara DR, West H, Chansky K, et al. Bronchioloalveolar carcinoma: a model for investigating the biology of epidermal growth factor receptor inhibition. Clin Cancer Res. 2004; 10(12 Pt 2): 4205s-4209s. [PubMed: 15217959]

81. Wislez M, Beer DG, Wistuba I, Cadranel J, Saijo N, Johnson BE. Molecular biology, genomics, and proteomics in bronchioloalveolar carcinoma. J Thorac Oncol. 2006; 1(9, suppl):S8-S12. [PubMed: 17410000]

82. Sakuma Y, Matsukuma S, Yoshihara M, et al. Epidermal growth factor receptor gene mutations in atypical adenomatous hyperplasias of the lung. Mod Pathol. 2007; 20(9):967-973. [PubMed: 17618248]

83. Dacic S, Sasatomi E, Swalsky PA, Kim DW, Finkelstein SD, Yousem SA. Loss of heterozygosity patterns of sclerosing hemangioma of the lung and bronchioloalveolar carcinoma indicate a similar molecular pathogenesis. Arch Pathol Lab Med. 2004; 128(8):880-884. [PubMed: 15270615]

84. Toonkel RL, Borczuk AC, Powell CA. TGF-beta signaling pathway in lung adenocarcinoma invasion. J Thorac Oncol. 2010; 5(2):153-157. [PubMed: 20101143]

85. Inamura K, Ninomiya $\mathrm{H}$, Ishikawa $\mathrm{Y}$, Matsubara $\mathrm{O}$. Is the epidermal growth factor receptor status in lung cancers reflected in clinicopathologic features? Arch Pathol Lab Med. 2010; 134(1):66-72. [PubMed: 20073607]

86. Ahn MJ, Lee J, Park YH, et al. Korean ethnicity as compared with white ethnicity is an independent favorable prognostic factor for overall survival in non-small cell lung cancer before and after the oral epidermal growth factor receptor tyrosine kinase inhibitor era. J Thorac Oncol. 2010; 5(8):1185-1196. [PubMed: 20592628]

87. Kawaguchi T, Matsumura A, Fukai S, et al. Japanese ethnicity compared with Caucasian ethnicity and never-smoking status are independent favorable prognostic factors for overall survival in nonsmall cell lung cancer: a collaborative epidemiologic study of the National Hospital Organization Study Group for Lung Cancer (NHSGLC) in Japan and a Southern California Regional Cancer Registry databases. J Thorac Oncol. 2010; 5(7):1001-1010. [PubMed: 20526205]

88. Kawaguchi T, Takada M, Kubo A, et al. Performance status and smoking status are independent favorable prognostic factors for survival in non-small cell lung cancer: a comprehensive analysis of 26,957 patients with NSCLC. J Thorac Oncol. 2010; 5(5):620-630. [PubMed: 20354456]

89. Meguid RA, Hooker CM, Harris J, et al. Long-term survival outcomes by smoking status in surgical and nonsurgical patients with non-small cell lung cancer: comparing never smokers and current smokers. Chest. 2010; 138(3):500-509. [PubMed: 20507946]

90. Riely GJ. Lung cancer in 'Never-smokers': molecular factors trump risk factors. Oncology (Williston Park). 2010; 24(1):38-40. [PubMed: 20187319]

91. Doran E, Jackman D. Fire without smoke: lung cancer in 'never-smokers'. Oncology (Williston Park). 2010; 24(1):40-43. [PubMed: 20187320]

92. Burns TF, Rudin CM. Lung cancer in 'never-smokers': beyond EGFR mutations and EGFR-TK inhibitors. Oncology (Williston Park). 2010; 24(1):48-49. [PubMed: 20187321] 
93. Kawaguchi T, Takada M, Kubo A, et al. Gender, histology, and time of diagnosis are important factors for prognosis: analysis of 1499 never-smokers with advanced non-small cell lung cancer in Japan. J Thorac Oncol. 2010; 5(7):1011-1017. [PubMed: 20502360]

94. Jian G, Songwen Z, Ling Z, et al. Prediction of epidermal growth factor receptor mutations in the plasma/pleural effusion to efficacy of gefitinib treatment in advanced non-small cell lung cancer. $\mathbf{J}$ Cancer Res Clin Oncol. 2010; 136(9):1341-1347. [PubMed: 20155428]

95. Faehling M, Eckert R, Kuom S, Kamp T, Stoiber KM, Schumann C. Benefit of erlotinib in patients with non-small-cell lung cancer is related to smoking status, gender, skin rash and radiological response but not to histology and treatment line. Oncology. 2010; 78(3-4):249-258. [PubMed: 20523085]

96. Reck M. A major step towards individualized therapy of lung cancer with gefitinib: the IPASS trial and beyond. Expert Rev Anticancer Ther. 2010; 10(6):955-965. [PubMed: 20553217]

97. Campbell L, Blackhall F, Thatcher N. Gefitinib for the treatment of non-small-cell lung cancer. Expert Opin Pharmacother. 2010; 11(8):1343-1357. [PubMed: 20426712]

98. Kono SA, Marshall ME, Ware KE, Heasley LE. The fibroblast growth factor receptor signaling pathway as a mediator of intrinsic resistance to EGFR-specific tyrosine kinase inhibitors in nonsmall cell lung cancer. Drug Resist Updat. 2009; 12(4-5):95-102. [PubMed: 19501013]

99. Eisenhauer EA, Therasse P, Bogaerts J, et al. New response evaluation criteria in solid tumours: revised RECIST guideline (version 1.1). Eur J Cancer. 2009; 45(2):228-247. [PubMed: 19097774]

100. Jackman D, Pao W, Riely GJ, et al. Clinical definition of acquired resistance to epidermal growth factor receptor tyrosine kinase inhibitors in non-small-cell lung cancer. J Clin Oncol. 2010; 28(2):357-360. [PubMed: 19949011]

101. Uramoto H, Mitsudomi T. Which biomarker predicts benefit from EGFR-TKI treatment for patients with lung cancer? Br J Cancer. 2007; 96(6):857-863. [PubMed: 17325698]

102. Asahina H, Yamazaki K, Kinoshita I, Yokouchi H, Dosaka-Akita H, Nishimura M. Nonresponsiveness to gefitinib in a patient with lung adenocarcinoma having rare EGFR mutations S768I and V769L. Lung Cancer. 2006; 54(3):419-422. [PubMed: 17045698]

103. Marchetti A, Milella M, Felicioni L, et al. Clinical implications of KRAS mutations in lung cancer patients treated with tyrosine kinase inhibitors: an important role for mutations in minor clones. Neoplasia. 2009; 11(10):1084-1092. [PubMed: 19794967]

104. Rho JK, Choi YJ, Lee JK, et al. The role of MET activation in determining the sensitivity to epidermal growth factor receptor tyrosine kinase inhibitors. Mol Cancer Res. 2009; 7(10):17361743. [PubMed: 19808904]

105. Chen HJ, Mok TS, Chen ZH, et al. Clinicopathologic and molecular features of epidermal growth factor receptor T790M mutation and c-MET amplification in tyrosine kinase inhibitor-resistant Chinese non-small cell lung cancer. Pathol Oncol Res. 2009; 15(4):651-658. [PubMed: 19381876]

106. Uramoto H, Iwata T, Onitsuka T, Shimokawa H, Hanagiri T, Oyama T. Epithelial-mesenchymal transition in EGFR-TKI acquired resistant lung adenocarcinoma. Anticancer Res. 2010; 30(7): 2513-2517. [PubMed: 20682976]

107. Zhang W, Stabile LP, Keohavong P, et al. Mutation and polymorphism in the EGFR-TK domain associated with lung cancer. J Thorac Oncol. 2006; 1(7):635-647. [PubMed: 17409930]

108. Kook EH, Kim YM, Kim HT, et al. Prognostic value of E-cadherin expression in non-small cell lung cancer treated with gefitinib. Oncol Res. 2010; 18(9):445-451. [PubMed: 20524402]

109. Ullrich RT, Zander T, Neumaier B, et al. Early detection of erlotinib treatment response in NSCLC by $3^{\prime}$-deoxy- $3^{\prime}$-[F]-fluoro-L-thymidine ([F]FLT) positron emission tomography (PET). PLoS ONE. 2008; 3(12):e3908. [PubMed: 19079597]

110. Wong MK, Lo AI, Lam B, Lam WK, Ip MS, Ho JC. Erlotinib as salvage treatment after failure to first-line gefitinib in non-small cell lung cancer. Cancer Chemother Pharmacol. 2010; 65(6): 1023-1028. [PubMed: 19680652]

111. Costa DB, Nguyen KS, Cho BC, et al. Effects of erlotinib in EGFR mutated non-small cell lung cancers with resistance to gefitinib. Clin Cancer Res. 2008; 14(21):7060-7067. [PubMed: 18981003] 
112. Kuo CH, Lin SM, Lee KY, et al. Subsequent chemotherapy improves survival outcome in advanced non-small-cell lung cancer with acquired tyrosine kinase inhibitor resistance. Clin Lung Cancer. 2010; 11(1):51-56. [PubMed: 20085868]

113. Manson GV, Ma PC. Response to pemetrexed chemotherapy in lung adenocarcinomabronchioloalveolar carcinoma insensitive to erlotinib. Clin Lung Cancer. 2010; 11(1):57-60. [PubMed: 20085869]

114. Tang Z, Du R, Jiang S, et al. Dual MET-EGFR combinatorial inhibition against T790M-EGFRmediated erlotinib-resistant lung cancer. Br J Cancer. 2008; 99(6):911-922. [PubMed: 19238632]

115. Regales L, Gong Y, Shen R, et al. Dual targeting of EGFR can overcome a major drug resistance mutation in mouse models of EGFR mutant lung cancer. J Clin Invest. 2009; 119(10):3000_ 3010. [PubMed: 19759520]

116. Sawai A, Chandarlapaty S, Greulich H, et al. Inhibition of Hsp90 down-regulates mutant epidermal growth factor receptor (EGFR) expression and sensitizes EGFR mutant tumors to paclitaxel. Cancer Res. 2008; 68(2):589-596. [PubMed: 18199556]

117. Kim JE, Lee DH, Choi Y, et al. Epidermal growth factor receptor tyrosine kinase inhibitors as a first-line therapy for never-smokers with adenocarcinoma of the lung having asymptomatic synchronous brain metastasis. Lung Cancer. 2009; 65(3):351-354. [PubMed: 19157632]

118. Olmez I, Donahue BR, Butler JS, Huang Y, Rubin P, Xu Y. Clinical outcomes in extracranial tumor sites and unusual toxicities with concurrent whole brain radiation (WBRT) and Erlotinib treatment in patients with non-small cell lung cancer (NSCLC) with brain metastasis. Lung Cancer. 2010; 70(2):174-179. [PubMed: 20207442]

119. Lee YJ, Shim HS, Kang YA, et al. Dose effect of cigarette smoking on frequency and spectrum of epidermal growth factor receptor gene mutations in Korean patients with non-small cell lung cancer. J Cancer Res Clin Oncol. 2010; 136(12):1937-1944. [PubMed: 20237940]

120. Soda M, Choi YL, Enomoto M, et al. Identification of the transforming EML4-ALK fusion gene in non-small-cell lung cancer. Nature. 2007; 448(7153):561-566. [PubMed: 17625570]

121. Sasaki T, Rodig SJ, Chirieac LR, Jänne PA. The biology and treatment of EML4-ALK non-small cell lung cancer. Eur J Cancer. 2010; 46(10):1773-1780. [PubMed: 20418096]

122. Zhang X, Zhang S, Yang X, et al. Fusion of EML4 and ALK is associated with development of lung adenocarcinomas lacking EGFR and KRAS mutations and is correlated with ALK expression. Mol Cancer. 2010; 9:188. [PubMed: 20624322]

123. Takahashi T, Sonobe M, Kobayashi M, et al. Clinicopathologic features of non-small-cell lung cancer with EML4-ALK fusion gene. Ann Surg Oncol. 2010; 17(3):889-897. [PubMed: 20183914]

124. Shaw AT, Yeap BY, Mino-Kenudson M, et al. Clinical features and outcome of patients with non-small-cell lung cancer who harbor EML4-ALK. J Clin Oncol. 2009; 27(26):4247-4253. [PubMed: 19667264]

125. Yang, P.; Oliveira, A.; Wampfler, J., et al. Reduced disease-free survival associated with anaplastic lymphoma kinase translocation (ALK +) in lung adenocarcinoma patients with no cigarette smoking history; Paper presented at: American Society for Radiation Oncology; Chicago, IL. December 9-10, 2010;

126. Neal JW, Sequist LV. Exciting new targets in lung cancer therapy: ALK, IGF-1R, HDAC, and Hh. Curr Treat Options Oncol. 2010; 11(1-2):36-44. [PubMed: 20676809]

127. Raleigh ZT. A biopsychosocial perspective on the experience of lung cancer. J Psychosoc Oncol. 2010; 28(1):116-125. [PubMed: 20391069]

128. Gorlova OY, Weng SF, Zhang Y, Amos CI, Spitz MR. Aggregation of cancer among relatives of never-smoking lung cancer patients. Int J Cancer. 2007; 121(1):111-118. [PubMed: 17304511]

129. Broderick P, Wang Y, Vijayakrishnan J, et al. Deciphering the impact of common genetic variation on lung cancer risk: a genome-wide association study. Cancer Res. 2009; 69(16):66336641. [PubMed: 19654303]

130. Bailey-Wilson JE, Amos CI, Pinney SM, et al. A major lung cancer susceptibility locus maps to chromosome 6q23-25. Am J Hum Genet. 2004; 75(3):460-474. [PubMed: 15272417] 
131. Amos CI, Pinney SM, Li Y, et al. A susceptibility locus on chromosome $6 \mathrm{q}$ greatly increases lung cancer risk among light and never smokers. Cancer Res. 2010; 70(6):2359-2367. [PubMed: 20215501]

132. You M, Wang D, Liu P, et al. Fine mapping of chromosome 6q23-25 region in familial lung cancer families reveals RGS17 as a likely candidate gene. Clin Cancer Res. 2009; 15(8):26662674. [PubMed: 19351763]

133. Wang M, Vikis HG, Wang Y, et al. Identification of a novel tumor suppressor gene p34 on human chromosome 6q25.1. Cancer Res. 2007; 67(1):93-99. [PubMed: 17210687]

134. Amos CI, Wu X, Broderick P, et al. Genome-wide association scan of tag SNPs identifies a susceptibility locus for lung cancer at 15q25.1. Nat Genet. 2008; 40(5):616-622. [PubMed: 18385676]

135. Hung RJ, McKay JD, Gaborieau V, et al. A susceptibility locus for lung cancer maps to nicotinic acetylcholine receptor subunit genes on 15q25. Nature. 2008; 452(7187):633-637. [PubMed: 18385738]

136. Liu P, Vikis HG, Wang D, et al. Familial aggregation of common sequence variants on 15q24-25.1 in lung cancer. J Natl Cancer Inst. 2008; 100(18):1326-1330. [PubMed: 18780872]

137. McKay JD, Hung RJ, Gaborieau V, et al. EPIC Study. Lung cancer susceptibility locus at 5p15.33. Nat Genet. 2008; 40(12):1404-1406. [PubMed: 18978790]

138. Rafnar T, Sulem P, Stacey SN, et al. Sequence variants at the TERT-CLPTM1L locus associate with many cancer types. Nat Genet. 2009; 41(2):221-227. [PubMed: 19151717]

139. Spitz MR, Amos CI, Dong Q, Lin J, Wu X. The CHRNA5-A3 region on chromosome 15q24-25.1 is a risk factor both for nicotine dependence and for lung cancer. J Natl Cancer Inst. 2008; 100(21):1552-1556. [PubMed: 18957677]

140. Thorgeirsson TE, Geller F, Sulem P, et al. A variant associated with nicotine dependence, lung cancer and peripheral arterial disease. Nature. 2008; 452(7187):638-642. [PubMed: 18385739]

141. Wang Y, Broderick P, Webb E, et al. Common 5p15.33 and 6p21.33 variants influence lung cancer risk. Nat Genet. 2008; 40(12):1407-1409. [PubMed: 18978787]

142. Yang P, Li Y, Jiang R, et al. A rigorous and comprehensive validation: common genetic variations and lung cancer. Cancer Epidemiol Biomarkers Prev. 2010; 19(1):240-244. [PubMed: 20056643]

143. Li Y, Sheu CC, Ye Y, et al. Genetic variants and risk of lung cancer in never smokers: a genomewide association study. Lancet Oncol. 2010; 11(4):321-330. [PubMed: 20304703]

144. Landi MT, Chatterjee N, Caporaso NE, et al. GPC5 rs2352028 variant and risk of lung cancer in never smokers. Lancet Oncol. 2010; 11(8):714-716. [PubMed: 20688270]

145. Yang P, Jen J, Li Y, et al. Lancet Oncol. 2010; 11:716. authors' reply.

146. Veugelers M, Vermeesch J, Reekmans G, Steinfeld R, Marynen P, David G. Characterization of glypican-5 and chromosomal localization of human GPC5, a new member of the glypican gene family. Genomics. 1997; 40(1):24-30. [PubMed: 9070915]

147. Blackhall FH, Merry CL, Davies EJ, Jayson GC. Heparan sulfate proteoglycans and cancer. Br J Cancer. 2001; 85(8):1094-1098. [PubMed: 11710818]

148. Yang P, Ebbert JO, Sun Z, Weinshilboum RM. Role of the glutathione metabolic pathway in lung cancer treatment and prognosis: a review. J Clin Oncol. 2006; 24(11):1761-1769. [PubMed: 16603718]

149. Kiyohara C, Wakai K, Mikami H, Sido K, Ando M, Ohno Y. Risk modification by CYP1A1 and GSTM1 polymorphisms in the association of environmental tobacco smoke and lung cancer: a case-control study in Japanese nonsmoking women. Int J Cancer. 2003; 107(1):139-144. [PubMed: 12925969]

150. Bennett WP, Alavanja MC, Blomeke B, et al. Environmental tobacco smoke, genetic susceptibility, and risk of lung cancer in never-smoking women. J Natl Cancer Inst. 1999; 91(23):2009-2014. [PubMed: 10580025]

151. Weinberg CR, Sandler DP. Gene-by-environment interaction for passive smoking and glutathione S-transferase M1? J Natl Cancer Inst. 1999; 91(23):1985-1986. [PubMed: 10580013]

152. Nyberg F, Hou SM, Hemminki K, Lambert B, Pershagen G. Glutathione S-transferase mu1 and $\mathrm{N}$-acetyltransferase 2 genetic polymorphisms and exposure to tobacco smoke in nonsmoking and 
smoking lung cancer patients and population controls. Cancer Epidemiol Biomarkers Prev. 1998; 7(10):875-883. [PubMed: 9796632]

153. Zhou W, Liu G, Miller DP, et al. Polymorphisms in the DNA repair genes XRCC1 and ERCC2, smoking, and lung cancer risk. Cancer Epidemiol Biomarkers Prev. 2003; 12(4):359-365. [PubMed: 12692111]

154. Yin J, Li J, Ma Y, Guo L, Wang H, Vogel U. The DNA repair gene ERCC2/XPD polymorphism Arg 156Arg (A22541C) and risk of lung cancer in a Chinese population. Cancer Lett. 2005; 223(2):219-226. [PubMed: 15896456]

155. Cohet C, Borel S, Nyberg F, et al. Exon 5 polymorphisms in the O6-alkylguanine DNA alkyltransferase gene and lung cancer risk in non-smokers exposed to second-hand smoke. Cancer Epidemiol Biomarkers Prev. 2004; 13(2):320-323. [PubMed: 14973087]

156. Vogel U, Christensen J, Wallin H, et al. Polymorphisms in genes involved in the inflammatory response and interaction with NSAID use or smoking in relation to lung cancer risk in a prospective study. Mutat Res. 2008; 639(1-2):89-100. [PubMed: 18164040]

157. Olivo-Marston SE, Yang P, Mechanic LE, et al. Childhood exposure to secondhand smoke and functional mannose binding lectin polymorphisms are associated with increased lung cancer risk. Cancer Epidemiol Biomarkers Prev. 2009; 18(12):3375-3383. [PubMed: 19959685]

158. Shen M, Vermeulen R, Rajaraman P, et al. Polymorphisms in innate immunity genes and lung cancer risk in Xuanwei, China. Environ Mol Mutagen. 2009; 50(4):285-290. [PubMed: 19170196]

159. Lee KM, Shen M, Chapman RS, et al. Polymorphisms in immunoregulatory genes, smoky coal exposure and lung cancer risk in Xuan Wei, China. Carcinogenesis. 2007; 28(7):1437-1441. [PubMed: 17361014]

160. Wang LI, Neuberg D, Christiani DC. Asbestos exposure, manganese superoxide dismutase (MnSOD) genotype, and lung cancer risk. J Occup Environ Med. 2004; 46(6):556-564. [PubMed: 15213518]

161. Senn O, Russi EW, Imboden M, Probst-Hensch NM. alpha1-Antitrypsin deficiency and lung disease: risk modification by occupational and environmental inhalants. Eur Respir J. 2005; 26(5):909-917. [PubMed: 16264055] 